\title{
Instalasi Sistem Pengairan Area Persawahan untuk Meningkatkan Produktivitas Tanaman Jagung
}

\author{
Tri Wahyono*, M. Budi N. Rahman, Fitroh Anugerah K. Yudha, Rahmad K. Adi \\ Universitas Muhammadiyah Yogyakarta \\ E-mail: triwahyono@umy.ac.id, budinurrahman@umy.ac.id, fitroh.anugerah.2010@ft.umy.ac.id, \\ rahmad.kuncoro.2016@ft.umy.ac.id
}

Diterima: Mei 2021 | Dipublikasikan: Juni 2021

\begin{abstract}
ABSTRAK
Lahan persawahan di Desa Ngleses sangat membutuhkan suplai air untuk kebutuhan proses pertanian. Para petani hanya mengandalkan air pada musim penghujan dan aliran irigasi. Pada musim kemarau, para petani hanya dapat mengambil air dari sungai menggunakan pompa yang dialirkan melalui pipa. Petani harus mengeluarkan biaya yang cukup banyak untuk menyewa pompa dan memasang instalasi pipa yang digunakan, belum lagi waktu yang dibutuhkan sangat lama sehingga biaya yang dibutuhkan cukup mahal. Kegiatan pengabdian ini bertujuan membuat instalasi perpipaan untuk membantu petani lebih mudah dalam mendapatkan air saat mulai mengolah lahan pertanian. Pembuatan instalasi perpipaan ini dibantu oleh masyarakat sekitar sehingga proses pemasangan pipa dapat dilakukan dengan cepat. Hasil dari pembuatan instalasi pipa di area persawahan ini sangat bermanfaat bagi petani dan masyarakat sekitar Dusun Sidorejo, Desa Ngleses, Kec. Juwangi, Kab. Boyolali. Total panjang instalasi pipa yang terpasang yaitu $1050 \mathrm{~m}$. Luas lahan yang mampu teraliri kurang lebih 10 hektar. Manfaat yang dapat dirasakan oleh masyarakat adalah a) waktu penyiraman area tanaman jagung lebih singkat, b) biaya yang dibutuhkan untuk pengairan lebih murah, c) pengolahan lahan pertanian tidak bergantung pada musim penghujan, d) hasil panen yang didapat oleh petani juga lebih banyak.
\end{abstract}

Kata kunci: instalasi, perpipaan, area persawahan

\section{ABSTRACT}

The fields in Ngleses Village highly require water supply for agricultural processing needs. Previously, farmers solely relied on the water in the rainy season and irrigation. In the dry season, they used to collect water from the river using pumps flowing through pipes. They had to spend much money to rent the pumps and install the pipes, not to mention the long time required, resulting in quite expensive costs. This service activity aimed to make pipe installation to help farmers obtain water easily for their agriculture. The local community assisted in the making of this pipe installation, thereby completed quickly. The pipe installation in the fields is beneficial for farmers and the community around Sidorejo Hamlet, Ngleses Village, Juwangi District, Boyolali Regency. The total length of the pipes installed is 1050 $m$, irrigating approximately 10 hectares of fields. It benefits the community in terms of (a) shorter time to water the maize crop area, (b) cheaper irrigation costs, (c) agricultural land processing no longer depends on the rainy season, and (d) higher crop yields.

Keywords: installation, piping, rice fields

\section{PENDAHULUAN}

Aktivitas pertanian di Dusun Sidorejo, Desa Ngleses, Kab. Boyolali dilaksanakan menyesuaikan pergantian musim pada umumnya yang terjadi di Indonesia yaitu musim penghujan dan musim kemarau. Pada saat musim penghujan, masyarakat cenderung akan menanam padi, sedangkan pada musim kemarau penduduk akan menanam jagung. Kedua komoditas pertanian itulah yang menjadi mata pencaharian sebagian besar penduduk di Desa Ngleses. Dengan demikian, dapat dikatakan sebagian besar penduduk Desa Ngleses bekerja sebagai petani dengan komoditas pertanian padi dan jagung.

Lokasi Desa Ngleses merupakan salah satu desa di Kab. Boyolali yang terpisah dari wilayah kabupaten karena letaknya berada di wilayah Kabupaten Purwodadi. Dengan kondisi tersebut, 
akses menuju Desa Ngleses sangat minim jangkauan pembangunan fasilitas jalan raya. Kondisi jalan dan area persawahan di Desa Ngeleses juga kurang diperhatikan oleh Pemerintah Kabupaten Boyolali. Salah satu dampak dari kondisi tersebut adalah sistem irigasi dan perairan sawah sangat minim. Pada musim kemarau, masyarakat sangat kesulitan mendapatkan air untuk kebutuhan pengairan sawah karena letak Desa Ngleses yang berada di atas permukaan sungai sehingga air tidak mampu mengalir ke area persawahan secara langsung. Permasalahan pengelolaan air irigasi akan timbul jika terjadi kekurangan air di petak sawah. Pengelolaan sumber daya air untuk pendistribusian dan pengalokasian air secara efektif dan efisien pada kondisi dan waktu yang tepat dan bermanfaat bagi masyarakat khususnya petani (Amri, dkk., 2018).

Selain lahan datar merupakan lahan yang mempunyai kemiringan sangat kecil, kondisi tanah yang kering dan retak (Gambar 1) sehingga tidak dimungkinkan untuk penerapan irigasi pipa bertekanan dengan sistem gravitasi. Pada dasarnya, aliran dalam pipa dapat diciptakan terbuka (tidak penuh), sehingga sifat dan karakteristik aliran dapat disamakan seperti aliran pada saluran terbuka. Dengan sifat dan karakteristik aliran terbuka, diharapkan irigasi pipa tidak memerlukan energi yang besar sehingga aliran yang terjadi dapat mengalirkan air irigasi sesuai dengan kebutuhan tanpa terjadi efek negatif seperti sedimentasi (Rahmandani dkk., 2014).

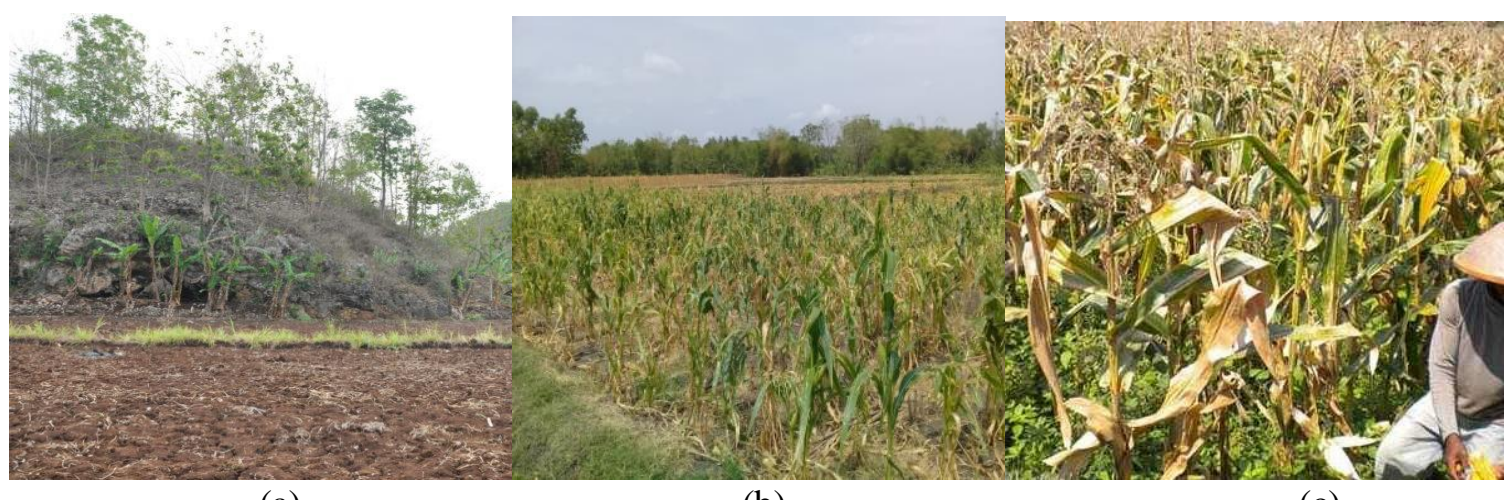

(a)

(b)

(c)

Gambar 1. (a) Kondisi lahan pertanian yang kering sebelum ditanami jagung,

(b) Lahan pertanian jagung dalam kondisi kekurangan air, dan (c) Panen jagung yang tidak maksimal karena kekurangan air

Pemberian air pada lahan sawah telah menjadi prioritas pembangunan pertanian selama beberapa Pelita, tetapi pengairan pada lahan kering belum mendapat perhatian dari pemerintah (Kurnia, 2004). Pada lahan sawah tadah hujan emisi gas $\mathrm{CH} 4$ berkisar antara 71-217 mg CH4/m2 /hari (Setyanto et al. dalam Naharia, et al, 2005). Dalam kondisi tersebut, petani di Desa Ngleses tidak dapat menghasilkan panin jagung yang maksimal karena proses perawatan tanaman yang terkendala oleh suplai air. Petani mengalami kendala biaya yang dibutuhkan untuk perawatan selama proses sebelum tanam, masa tanam, hingga panin. Berdasarkan kondisi itulah, petani tidak dapat berharap mendapatkan hasil panin maksimal sehingga terkesan hanya secukupnya, yaitu petani mendapat hasil penjualan yang sesuai dengan modal untuk proses penanaman dan perawatan.

Aktivitas penduduk hanya mengandalkan pada sektor pertanian dengan memanfaatkan lahan untuk pertanian padi pada musim penghujan dan pertanian jagung pada musim kemarau. Pada musim kemarau, lahan pertanian tidak dapat teraliri air karena letaknya lebih tinggi sekitar $\pm 8 \mathrm{~m}$ dari permukaan sungai sehingga masyarakat harus menggunakan pompa untuk dapat mengangkat air agar dapat mengairi area persawahan yang akan digunakan untuk menanam jagung. Hingga kini, permasalahan yang dihadapi mitra dalam kegiatan pertanian adalah kurangnya asupan sistem perairan di area persawahan pada musim kemarau.

Untuk mendapatkan air yang dialirkan ke area persawahan, masyarakat harus menggunakan pompa yang disewa selama \pm 10 jam sehingga dapat memberikan kebutuhan air yang cukup untuk lahan pertanian, itupun hanya mampu mengairi beberapa petak. Selebihnya, sewa pompa 
harus ditambah lagi waktunya dan berdampak pada penambahan biaya. Dengan kondisi tersebut, masyarakat harus mengeluarkan biaya yang cukup banyak hanya untuk mengairi area persawahan. Biaya yang dibutuhkan untuk sewa pompa sebesar Rp50.000 per jam sehingga besarnya biaya yang harus disiapkan untuk mengairi sawah dapat dijumlahkan sesuai waktu yang diperlukan selama proses pengairan.

Infrastruktur saluran irigasi yang disediakan pemerintah tidak mampu mengalirkan air yang dibutuhkan oleh masyarakat setiap saat sehingga masyarakat harus mengangkat air dari sungai atau bendungan yang ada di sekitar Desa Ngleses. Untuk dapat mengalirkan air dari bendungan ke area persawahan, masyarakat membutuhkan instalasi perpipaan yang mampu menjangkau seluruh area persawahan masyarakat. Dengan demikian, dibutuhkan sistem pengairan sawah yang mampu dimanfaatkan oleh masyarakat setiap saat untuk kebutuhan pertanian baik pada musim penghujan maupun kemarau. Berdasarkan kondisi lahan pertanian dan kebutuhan masyarakat terhadap sistem pengairan di area persawahan khususnya pada musim kemarau. Kegiatan pengabdian kepada masyarakat melalui Program Kemitraan Masyarakat di Dusun Sidorejo, Desa Ngleses ini akan merancang sistem pengairan area sawah untuk antisipasi musim kemarau dengan kebutuhan air yang diambil dari sumber air atau Bendungan Dusun Sidorejo (Gambar 2) yang berada di sekitar Desa Ngleses.

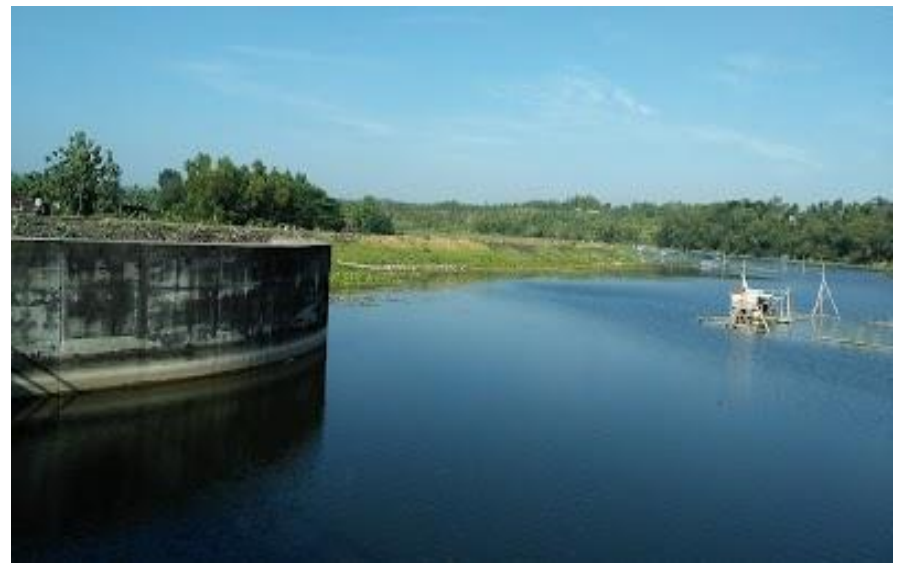

Gambar 2. PLTA dan Bendungan di Sekitar Desa Ngleses

Kurangnya suplai kebutuhan air untuk area persawahan pada musim kemarau menyebakan aktivitas pertanian di Dusun Sidorejo terhambat. Ketika musim kemarau panjang terjadi, sangat terasa sekali penderitaan bagi masyarakat, khususnya para petani, karena air dalam jumlah terbatas sangat berharga sekali. Oleh karenanya untuk mengatasi persoalan air pada musim kemarau, perlu melakukan manajemen air dengan tepat (Supadi, 2008). Untuk mengatasi masalah tersebut, salah satu solusi alternatif adalah membuat rancangan instalasi perpipaan untuk sistem pengairan di area persawahan. Perancangan sistem pengelolaan air tersebut dapat dimanfaatkan pada musim kemarau ketika kebutuhan suplai air sangat tinggi. Pengelolaan air di lahan sawah tidak hanya menyangkut sistem irigasi, tetapi juga sistem drainase pada saat tertentu untuk mengurangi kuantitas air maupun mengganti air yang lama, sehingga memberikan peluang terjadinya sirkulasi oksigen dan hara (Taufik dkk., 2016).

Penggunaan pipa sebagai saluran tertutup di bidang irigasi dewasa ini banyak diterapkan di berbagai negara termasuk di Indonesia, sebagai upaya untuk mengoptimalkan pemanfaatan air irigasi. Dengan sistem ini, kekurangan air di sepanjang penyaluran dapat ditekan, sehingga efisiensi penyaluran air irigasi dapat ditingkatkan (Rahmandani dkk., 2014). Tujuan adanya pengairan adalah agar dapat menunjang penyediaan air untuk kebutuhan dan peningkatan hasil produksi. Dalam rangka mencapai tujuan tersebut maka sistem pengairan harus dapat merehabilitasi sistem pengairan dan perluasan pengairan (Azkia, 2016). Dengan kebutuhan suplai air ke area persawahan yang memadahi, masyarakat dapat mengoptimalkan lahan pertanian secara maksimal sehingga hasil pertanian yang diperoleh masyarakat dapat meningkat. 


\section{METODE PELAKSANAAN}

Metode yang digunakan dalam program kemitraan masyarakat ini adalah metode problem solving. Implementasi pelaksanaan metode tersebut dengan melibatkan mitra dan masyarakat pada setiap proses kegiatan (Angin dan Nusanto, 2020). Metode yang diterapkan pada kegiatan pengabdian kepada masyarakat ini adalah perancangan sistem perpipaan pada area persawahan. Instalasi sistem perpipaan tersebut akan dimanfaatkan ketika cadangan air tanah sekitar persawahan mulai habis, sedangkan kebutuhan air sangat banyak. Kondisi tersebut terjadi pada musim kemarau. Dengan adanya perancangan sistem pengairan pada daerah persawahan tersebut, distribusi kebutuha air pada daerah tersebut dapat tercukupi pada setiap lahan persawahan yang akan digunakan sebagai lahan pertanian. Jaringan irigasi sebagai media untuk memenuhi kebutuan air pertanian perlu dikelola secara efektif dan efisien, salah satu cara pengelolaan air dari bawah tanah dan sungai tersebut dimanfaatkan secara optimal menggunakan sistem yang tepat dengan pompa yang didistribusikan ke area persawahan sesuai kapasitas air yang tersedia (Hariyanto, 2018),

Perencanaan sistem jaringan pipa irigasi dibagi menjadi dua tahap, yaitu perencanaan pipa utama dan cabang. Kedua perencanaan pipa dilakukan dengan metode analisis yang sama namun dengan hasil yang berbeda. Analisis head di inlet dan outlet dilakukan pertama kali untuk menentukan metode distribusi yang digunakan, dengan pompa atau gravitasi (Ramadhan, 2015). Secara umum, tahapan proses pelaksanaan pengabdian kepada masyarakat melalu Program Kemitraan Masyarakat dapat dilihat pada diagram alir berikut.

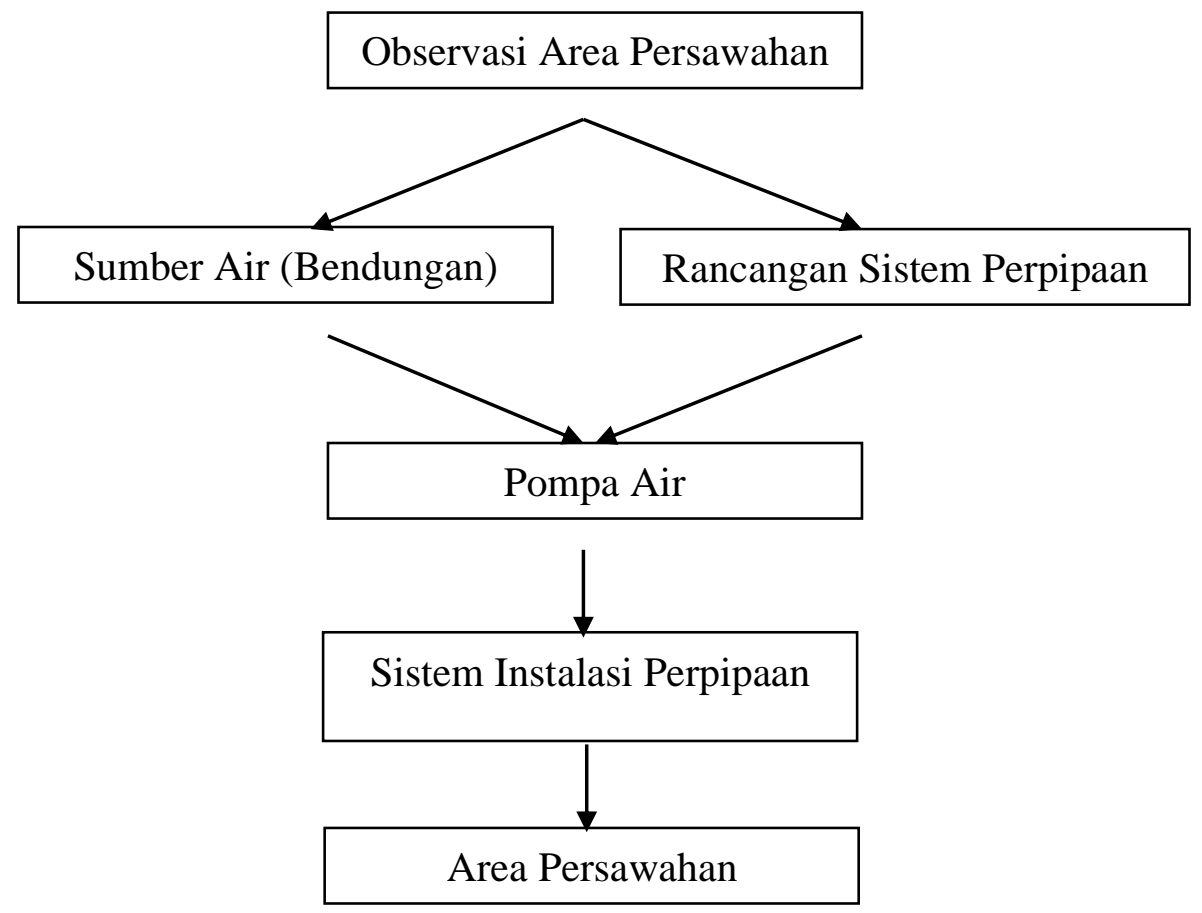

Diagram 1. Tahapan Proses Pengabdian Perancangan Sistem Perairan Area Persawahan

\section{HASIL KEGIATAN}

Proses perancangan dan realisasi program sistem pengairan di area persawahan sangat didukung sepenuhnya dan dibantu oleh warga dan kelompok tani setempat. Warga terlibat aktif dalam membantu merancang dan pemasangan pipa untuk implementasi instalasi perpipaan di area persawahan. Kelompok Tani Lestari Maju merupakan kelompok tani yang ada di Dusun Sidorejo dan secara aktif membantu program pengabdian kepada masyarakat, baik dalam proses 
perancangan hingga proses instalasi perpipaan. Instalasi pipa yang dipasang bersumber dari Bendungan PLTA yang ada Dusun Sidorejo hingga mengarah ke area persawahan sepanjang $1050 \mathrm{~m}$ dengan rincian $800 \mathrm{~m}$ menggunakan pipa dan 250 selebihnya menggunakan selang yang digunakan untuk menjangkau area persawahan yang tidak bisa diakses menggunakan pipa dengan ukuran 3 dim. Berikut dokumentasi dukungan mitra dan bantuan warga masyarakat dalam proses pelaksanaan Program Kemitraan Masyarakat (PKM) dalam kegiatan instalasi perpipaan sistem pengairan area persawahan di Dusun Sidorejo, Desa Ngleses, Kec. Juwangi, Kab. Boyolali (Gambar 3).

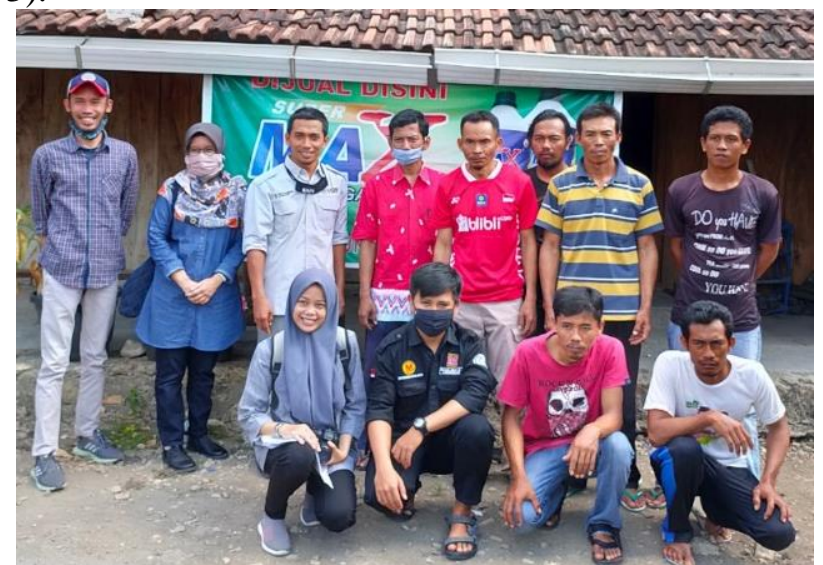

Gambar 3. Tim Pengabdian UMY dan Kelompok Tani Lestari Maju

Pemasangan pipa yang bersumber dari Bendungan PLTA yang ada di Dusun Sidorejo dilengkapi dengan pompa berkapasitas $6.5 \mathrm{Pk}$ yang ditempat di tepi bendungan. Pompa tersebut didapat dari bantuan yang diberikan oleh Pemerintah Kabupaten Boyolali. Untuk memastikan pompa dapat berfungsi mengangkat dan mengalirkan air ke area persawahan, warga menempatkan salah satu anggota kelompok tani yang menjaga dan mengawasi proses pengairan selama pompa tersebut diaktifkan. Untuk memastikan air sampai ke area persawahan, salah satu anggota kelompok tani ditempatkan di area persawahan untuk mengawasi aliran air yang sampai ke lahan pertanian. Berikut dokumentasi kegiatan Program Kemitraan Masyarakat (PKM) (Gambar 4) yang dibantu oleh Kelompok Tani Lestari Maju dalam mengoperasikan pompa untuk mengangkat air dari bendungan dan mengalirkan ke area persawahan.

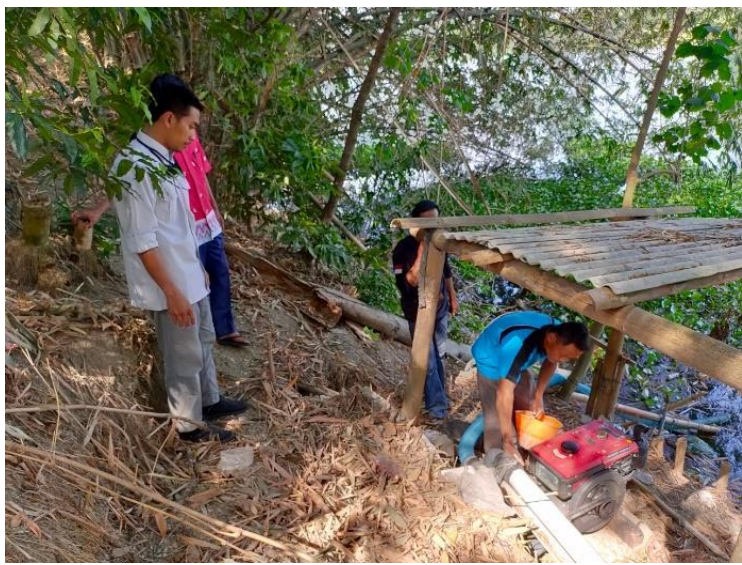

Gambar 4. Pengecekan Sumber Air dan Pemasangan Pompa di Tepi Bendungan

Proses pemasangan saluran pipa dibantu sepenuhnya oleh warga masyarakat dan Kelompok Tani Lestari Maju. Pipa diarahkan ke area persawahan melalui lahan perkebunan dan area pemukiman warga. Pipa yang dipasang dari sumber air menuju lokasi pertama area pertanian berjarak sekirat $300 \mathrm{~m}$ dengan melintasi tepi dan tebing bendungan, area pemukiman warga, jalan pedesaan, dan lahan perkebunan. Warga dan kelompok tani di dusun Sidorejo sangat antusias membantu proses pemasangan saluran pipa tersebut. Kondisi dan suasana tersebut dirasa sangat spesial dan berkesan karena proses instalasi perpipaam yang diarahkan untuk pengairan 
area pertanian secara permanen tersebut merupakan harapan dan kebutuhan masyarakat untuk menyuplai air ke persawahan sejak lama. Berikut dokumentasi proses pemasangan pipa yang dilaksanakan oleh warga dan kelompok tani lestari maju di Dusun Sidorejo (Gambar 5).

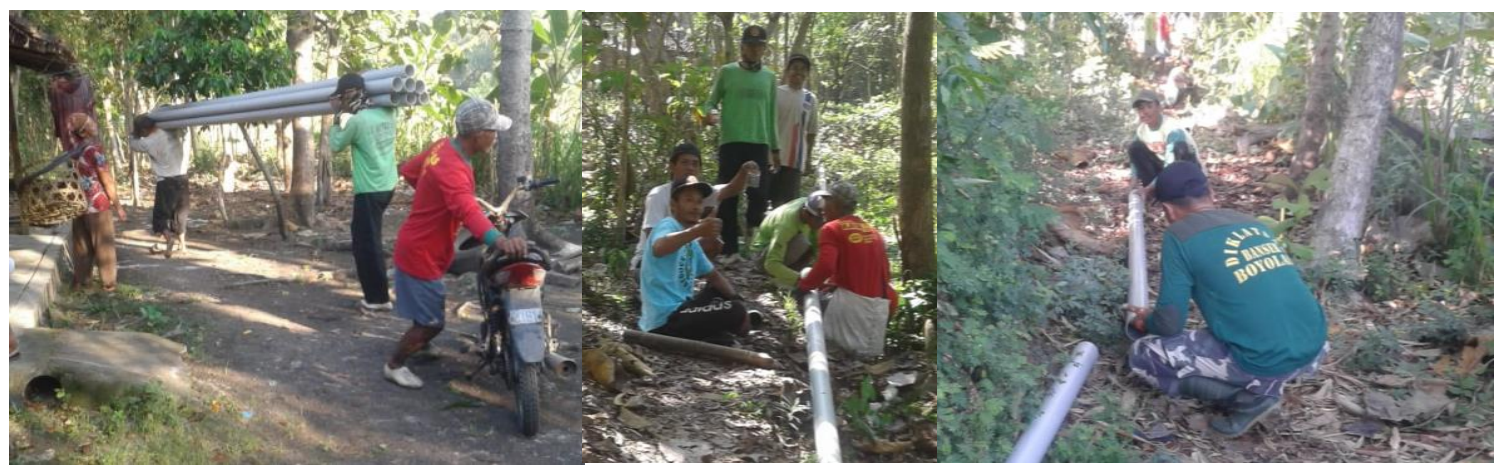

Gambar 5. Pemasangan Pipa Oleh Warga dan Kelompok Tani Lestari Maju

Instalasi pipa yang diarahkan ke area persawahan masyarakat melintas perkebunan dan pematang sawah hingga sampai ke lokasi persawahan pertama yang berdekatan dengan area pemukiman warga. Selain diletakkan di atas permukaan pematang sawah, instalasi perpipaan juga dipendam di tepian pematang sawah agar tidak menggangu akses jalan menuju persawahan saat membawa alat transportasi untuk membawa hasil panin dan keperluan perawatan lahan pertanian lainnya. Dengan demikian, seperti yang dijelaskan oleh Subagyono dkk. (2005). Hasil pemasangan pipa yang diarahkan ke area persawahan dapat dilihat pada Gambar 6.

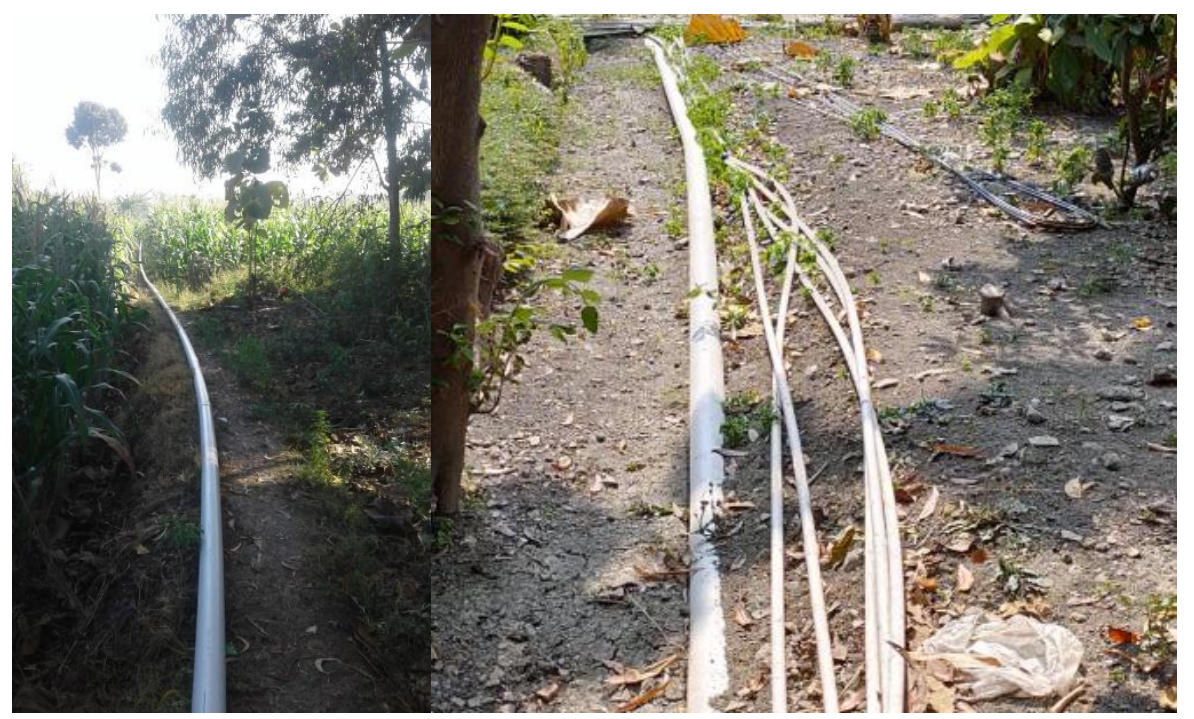

Gambar 6. Pipa Dipasang Melintasi Pemukiman Penduduk dan Galangan Lahan Pertanian

Instalasi perpipaan yang telah terpasang dapat kemudian diuji coba untuk mengairi lahan pertanian yang terdekat dengan sumber air. Sistem perpipaan yang dipasang di area persawahan terdekat dilengkapi dengan stop kran dan pipa dengan luaran 4 sisi agar air dapat dialirkan ke segala arah lahan pertanian. Uji coba dan pengecekan aliran proses pengairan diarahkan ke salah satu area terdekat luaran air di lahan pertanian yang berjarak kurang lebih $300 \mathrm{~m}$. Luaran aliran yang terdekat dengan area pemukiman dan sumber air ditunjukkan pada Gambar 7. Dari hasil uji coba tersebut, masyarakat sangat senang karena hasil instalasi dianggap lancar dan berhasil dibuktikan dengan luaran debit air yang mengalir melalui pipa sangat deras. Dengan kondisi tersebut, proses pengairan dapat berjalan dengan waktu yang lebih cepat dibanding sebelumnya. 


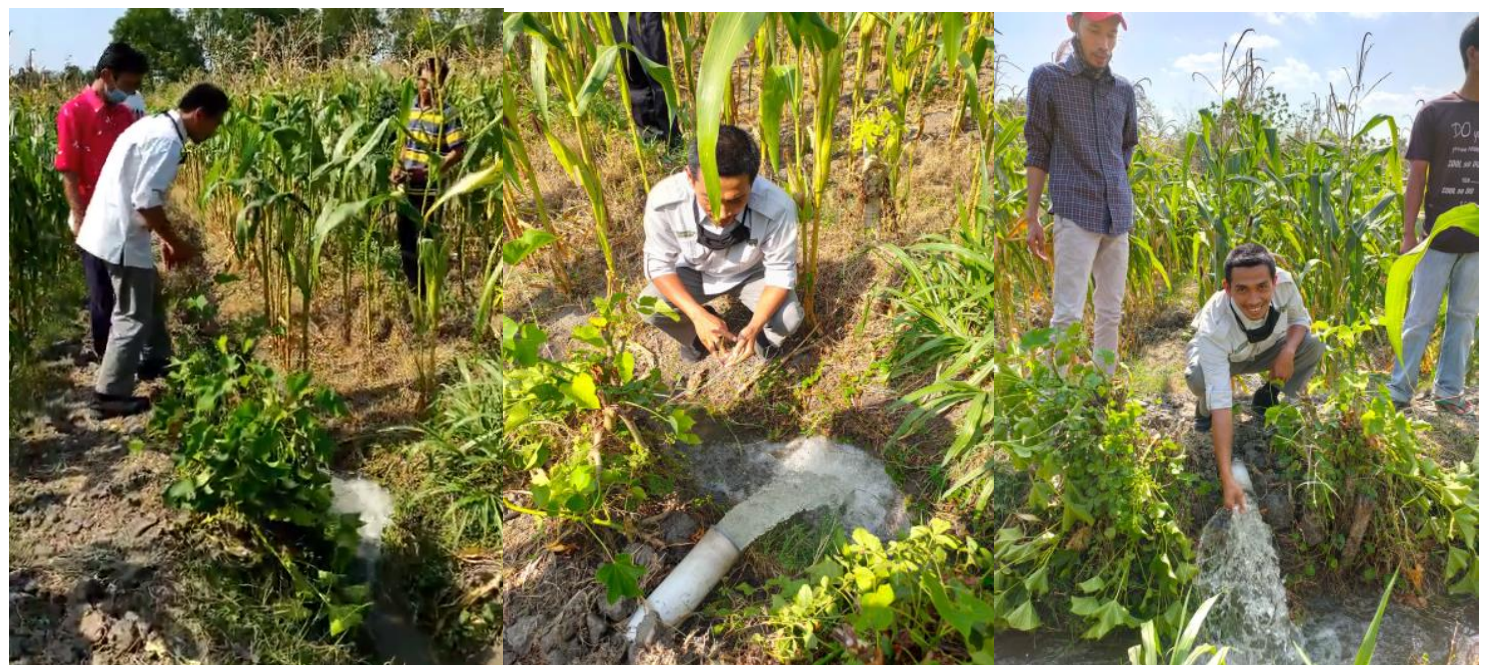

Gambar 7. Titik Keluar Air di Area Pertanian Warga

Setelah proses instalasi perpipaan untuk pengairan selesai, masyarakat merasa sangat terbantu dalam pengolahan lahan dan perawatan tanaman secara berkala dengan siklus yang teratur. Dengan adanya saluran air melalui pipa yang didukung oleh program pengabdian masyarakat UMY, petani merasa terbantu dalam pembiayaan proses pertanian. Produktivitas air dengan adanya input teknologi irigasi pipa dilakukan agar dapat diketahui pemberian air yang efisien dan mendapatkan produksi yang optimum (Fuadi dkk., 2016). Sebelum ada aliran air tersebut, biaya yang dikeluarkan oleh petani untuk mengairi area pertanian hanya sekitar 25.000/jam untuk area pertanian yang jauh bisa mencapai 50.000/jam (karena harus menggunakan 2 mesin) dengan kapasitas mesin 5.5 Pk dengan waktu yang dibutuhkan sekitar 10-14 jam. Setelah adanya pipanisasi, biaya yang dikeluarkan sebesar 25.000/ jam, tetapi dengan kapasitas mesin diesel lebih besar yaitu 6.5 Pk sehingga waktu yang dibutuhkan lebih cepat hanya sekitar 6-8 jam untuk lahan pertanian seluas $1 / 4$ hektar.

Sebelum pemasangan sistem perpipaan saat musim kemarau, dalam sehari petani hanya dapat mengairi 2-3 lahan petani (bergantung pada luas lahan dan kondisi kekeringan tanah). Setelah instalasi perpipaan tersebut terpasang, dalam sepekan petani dapat mengairi lahan pertanian milik petani mencapai 14-20 lahan. Diharapkan, setelah adanya pipanisasi, hasil panen bisa meningkat. Hasil panen di lahan yang kebutuhan airnya terpenuhi biasanya mencapai 6-8 ton perhektar (bergantung juga pada bibit dan pemupukan). Secara umum, petani sangat diuntungkan setelah adanya pipanisasi aliran perairan di area persawahan. Setelah mendekati masa berbuah, tanaman jagung yang sudah mendapat suplai air melalui sistem perpipaan yang dilaksanakan oleh Tim Pengabdian UMY dan kelompok tani lestari maju, tanaman jagung tumbuh subur dan segar. Ketinggian tanaman jagung mencapai lebih dari $2 \mathrm{~m}$ dan jagung yang dihasilkan lebih besar. Dengan hasil tersebut, masyarakat dapat meraup keuntungan saat musim panen yang lebih banyak karena biaya operasional selama masa tanam dan perawatan dapat ditekan dengan adanya instalasi sistem perpipaan untuk pengairan di area persawahan. Terpenuhinya kebutuhan air dalam kehidupan merupakan kunci utama bagi perkembangan suatu kegiatan dan menjadi elemen penting bagi keberlanjutan produktivitas perekonomian masyarakat (Pramono dan Andana, 2019). 


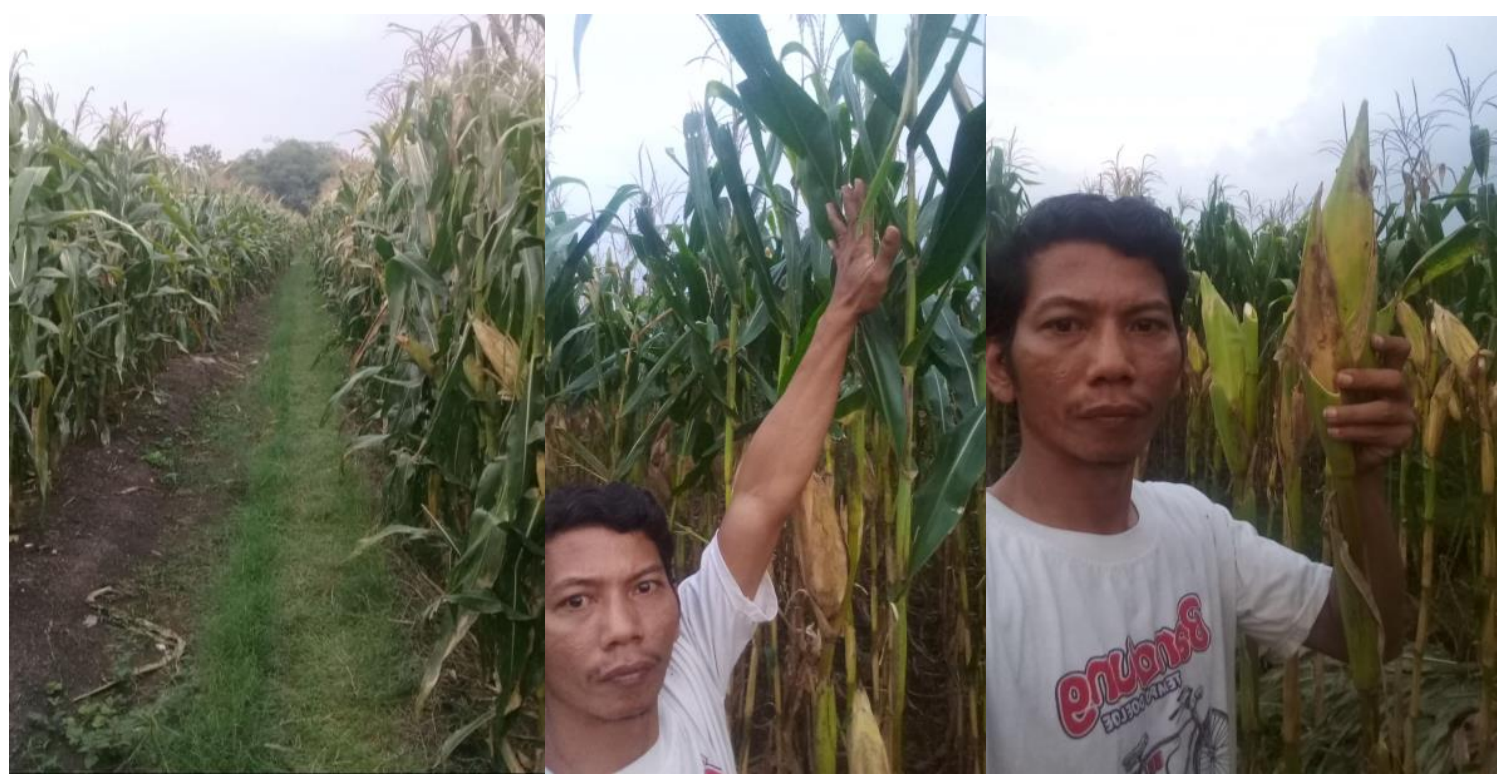

Gambar 8. Tanaman Jagung Setelah Menggunakan Sistem Pengairan Hasil Program PKM UMY

Demikian hasil program pengabdian yang dilakukan oleh tim pengabdian UMY yang dibantu sepenuhnya oleh Kelompok Tani Lestari Maju dan warga masyarakat Dusun Sidorejo. Kegiatan tersebut terlaksana atas izin dan dukungan Pemerintah Desa Ngleses yang diinisiasi melalui kegiatan kuliah kerja nyata yang dilansanakan oleh mahasiswa pada tahun ajaran 2018/2019 yang dilaksanakan di Dusun Sidorejo. Secara khusus, kegiatan pengabdian ini juga terlaksana atas dukungan dan peran aktif dari Bapak Budi Wahono selaku Sekretaris Desa Ngleses sekaligus sebagai anggota Kelompok Tani Lestari Maju dan warga Dusun Sidorejo. Kegiatan pengabdian Program Kemitraan Masyarakat (PKM) Perancangan Sistem Perpipaan untuk Pengairan Area Persawahan telah dipublikasikan juga melalui media massa elektronik Harian Jogja (01/11/2020) pada https://m.harianjogja.com/pengabdianumy/read/amp/, media sosial online melalui Youtube https://www.youtube.com/watch, dan instagram https://www.instagram.com/p/CG-F23VsMeToRyHY8XgYKxt6ZRtK6vx51nTuZ00/.

\section{KESIMPULAN DAN SARAN}

Setelah pemasangan instalasi perpipaan di area persawahan, petani mendapatkan kemudahan dalam suplai air selama proses penanaman dan perawatan tanaman. Tanaman jagung menjadi lebih segar dan subur serta buah jagung yang dihasilkan lebih besar. Biaya yang dikeluarkan untuk proses penanaman dan perawatan oleh petani lebih hemat hingga 50\% dan hasil panen juga meningkat sehingga keuntungan yang didapat lebih banyak. Untuk area seluas $1 / 4$ hektare petani mendapat hasil panin mencapai 6-8 ton. Dengan demikian, petani mendapat keuntungan yang lebih banyak dari hasil penjualan panin jagung karena biaya yang dikeluarkan selama operasional lebih sedikit ditambah lagi hasil panin yang didapat lebih banyak. Dengan kegiatan pengabdian kepada masyarakat oleh Tim Pengabdian UMY, diharapkan dapat meningkatkan kesejahteraan dan perekonomian masyarakat Dusun Sidorejo, Desa Ngleses, Boyolali.

\section{UCAPAN TERIMA KASIH}

Terima kasih kepada seluruh pihak yang telah membantu dan mendukung program pengabdian masyarakat "Instalasi Sistem Perairan Area Persawahan di Dusun Sidorejo, Desa Ngleses, Boyolali". Terima kasih kepada LP3M UMY yang telah memberikan kepercayaan dan dukungan penuh dalam pendanaan untuk melaksanakan program pengabdian masyarakat ini. 
Penulis juga berterima kasih kepada masyarakat Dusun Sidorejo dan Kelompok Tani Lestari Maju yang telah berpartisipasi sebagai mitra serta diucapkan terima kasih juga kepada Sekretaris Desa Ngleses Bpk. Budi Wahono, S.Pd. dan Kepala Desa Ngleses Bpk. Indri Widodo, S.H. yang telah memfasilitasi dan memotivasi masyarakat untuk senantiasa bekerja sama melaksanakan program ini dengan baik.

\section{DAFTAR PUSTAKA}

Amri, A., Hasan, I., \& Pasarai, M. (2019). Analisis Sistem Pipanisasi untuk Persawahan. Teknik Mesin" TEKNOLOGI", 19(1 Okt).

Angin, R., \& Nusanto, B. (2020). Penguatan Kelembagaan Panti Asuhan Untuk Membangun Kemandirian Finansial Melalui Pelatihan Kewirausahaan. Jurnal Pengabdian Masyarakat IPTEKS, 6(1), 1-8.

Azkia, R. (2016). Analisis Sistem Pengairan Sawah Masyarakat Gampong Bineh Blang Kabupaten Aceh Besar dalam Perspektif Akad Al-Musaqah (Doctoral dissertation, UIN Ar-Raniry Banda Aceh).

Fuadi, N. A., Purwanto, M. Y. J., \& Tarigan, S. D. (2016). Kajian kebutuhan air dan produktivitas air padi sawah dengan sistem pemberian air secara sri dan konvensional menggunakan irigasi pipa. Jurnal Irigasi, 11(1), 23-32.

Hariyanto. (2018). Analisis Penerapan Sistem Irigasi untuk Peningkatan Hasil Pertanian di Kecamatan Cepu Kabupaten Blora. Jurnal Civil Engineering. 2 (1), 29-34.

Kurnia, U. (2004). Prospek pengairan pertanian tanaman semusim lahan kering. Jurnal Litbang Pertanian, 23(4), 130-138.

Naharia, O., Saeni, M. S., Sabihan, S., \& Burhan, H. (2005). Teknologi Pengairan dan Pengolahan Tanah pada Budidaya Padi Sawah untuk Mitigasi Gas Metana (CH4). Berita Biologi, 7(4), 173-180.

Pramono, G. E., \& Andana, R. (2019). Analisis Kebutuhan Air Dan Pembangunan Sistem Pengairan Menggunakan Pompa Air Di Kampung Cengal Desa Karacak. Abdi Dosen: Jurnal Pengabdian Pada Masyarakat, 3(3), 216-221.

Rahmandani, D., Triyono, J., \& Ridwan, D. (2014). Desain Jaringan Irigasi Pipa pada Lahan Datar (Studi Kasus: Petak Tersier Pasir Salam 3 Kiri, Daerah Irigasi PanulisanCilacap). Jurnal Irigasi, 9(2), 75-85.

Ramadhan, M. R. (2015). Perencanaan Sistem Jaringan Perpipaan Bertekanan untuk Irigasi Padi Sawah di Balai Besar Penelitian Tanaman Padi (Subang, Jawa Barat). Departemen Teknik Sipil dan Lingkungan Fakultas Teknologi Pertanian Institut Pertanian Bogor Bogor.

Subagyono, K. Dariah, A., Surmaini, E., Kurnia, U. (2004). Pengelolaan Air pada Tanah Sawah. Buku: Tanah Sawah dan Teknologi Pengelolaanya. Pusat Penelitian dan Pengembangan Tanah dan Agroklimat. Badan Penelitian dan Pengembangan Pertanian, Departemen Pertanian.

Supadi, S. Pengkajian Penanganan Pemberian Air Irigasi di Petak Terisolir Ujung Saluran Irigasi pada Musim Kemarau. MEDIA KOMUNIKASI TEKNIK SIPIL, 17(1), 1-8. 
Taufik, M., Nappu, B., \& Djufry, F. (2014). Analisis pengelolaan air dalam usahatani padi pada lahan sawah irigasi di sulawesi selatan. Indonesian Agency for Agricultural Research and Development.

Zulkarnain, I. (2018). Irigasi dan Bangunan Irigasi. Repository LPPM Unila. Diakses dari http://repository.lppm.unila.ac.id/converted.pdf. 20/01/2021. 